THERYA, Abril, 2010

Vol.1(1): 75-90

DOI: 10.12933/therya-10-8

\title{
PUP GROWTH OF THE GUADALUPE FUR SEAL, Arctocephalus townsendi.
}

\author{
Juan-Pablo Gallo-Reynoso ${ }^{1 *}$, Ana-Luisa Figueroa-Carranza ${ }^{2}$
}

\section{Abstract}

Pups of the Guadalupe fur seal were captured, marked with hair bleach, measured and weighed between two and four times during their first year of life, during three consecutive years (1991, 1992 and 1993) conforming a sample of 132 pups of both sexes. The following parameters were measured: standard length, body mass, and axilar girth, these were measured in the first hours to days of birth when the pup still had attached a soft umbilical cord, and at 40, 145 and 220 days after birth. Mean birth body mass was $4.9 \pm 0.5 \mathrm{~kg}, n=17$ (males: $4.9 \pm 0.4 \mathrm{~kg}, n=7$; females: $4.9 \pm 0.5 \mathrm{~kg}$, $n=10$ ), mean length was $64.4 \pm 4.3 \mathrm{~cm}, n=17$ (males: $67.2 \pm 3.5 \mathrm{~cm}, n=7$; females: $62.5 \pm 3.7 \mathrm{~cm}, n=10$ ). Growth was exponential to 145 days and stabilized to 220 days at weaning age (weaning takes place between February and March at 9-10 months of age), mean weaner's body mass was $14 \pm 2.8 \mathrm{~kg}, n=13$ (males: $13.7 \pm 3.6 \mathrm{~kg}, n=5$; females: $14.3 \pm 2.0 \mathrm{~kg}, n=8$ ) with a mean length of $89.4 \pm 8 \mathrm{~cm}, n=13$ (males: $91.3 \pm$ $8.5 \mathrm{~cm}, n=5$; females: $86.4 \pm 6 \mathrm{~cm}, n=8$ ). Body mass was not significantly different between the sexes for the fur seal pups, although lengths were significantly different at birth and at several other stages. The curves of body mass-length relationship showed high variability, but nevertheless showed a high correlation, the body mass and length regression was significant $\left(r^{2}=0.7024, P<0.001\right)$. Much of this variability is caused by the long foraging trips of the females. This leads to drastic changes in pup body mass due to rapid milk intake during a mean of 5.03 days of female attendance and major body mass loss during female absence of a mean of 11.5 days.

Key words: Guadalupe fur seal, Arctocephalus townsendi, Isla Guadalupe, pup growth.

\section{Resumen}

Crías del lobo fino de Guadalupe fueron capturadas, marcadas con decolorante de pelo, medidas y pesadas de dos a cuatro veces durante su primer año de vida, en tres años consecutivos (1991, 1992 y 1993) conformando una muestra de 132 crías de ambos sexos. Se midieron los siguientes parámetros: longitud estándar, peso corporal y circunferencia axilar, estas fueron tomadas en los primeros días del nacimiento, cuando la cría aún tenía el cordón umbilical suave. Estas crías se midieron y pesaron a los 40,

${ }^{1}$ Centro de Investigación en Alimentación y Desarrollo. Unidad Guaymas. Carretera a Varadero Nacional km 6.6, Col. Las Playitas. Guaymas, Sonora 85480, México. E-mail: jpgallo@ciad.mx, autor corresponsal

2 Área de Protección de Flora y Fauna Islas del Golfo de California, Comisión Nacional de Áreas Naturales Protegidas. Isla Peruano, esquina Isla de la Rasa. Col. Lomas de Miramar, Guaymas, Sonora 85450, México 
145 y 220 días después de nacidas. El peso promedio al nacimiento fue de $4.9 \pm 0.5 \mathrm{~kg}$, $n=17$ (machos: $4.9 \pm 0.4 \mathrm{~kg}, n=7$; hembras: $4.9 \pm 0.5 \mathrm{~kg}, n=10$ ), la longitud promedio fue de $64.4 \pm 4.3 \mathrm{~cm}, n=17$ (machos: $67.2 \pm 3.5 \mathrm{~cm}, n=7$; hembras: $62.5 \pm 3.7 \mathrm{~cm}, n$ =10). El crecimiento fue exponencial hasta los 145 días en que se estabiliza hasta los 220 días, edad del destete (el destete sucede entre Febrero y Marzo a los 9-10 meses de edad). El peso promedio al destete para ambos sexos fue de $14 \pm 2.8 \mathrm{~kg}, n=13$ (machos: $13.7 \pm 3.6 \mathrm{~kg}, n=5$; hembras: $14.3 \pm 2.0 \mathrm{~kg}, n=8$ ) con una longitud promedio de 89.4 $\pm 8 \mathrm{~cm}, n=13$ (machos: $91.3 \pm 8.5 \mathrm{~cm}, n=5$; hembras: $86.4 \pm 6 \mathrm{~cm}, n=8$ ). Los pesos para ambos sexos no fueron significativamente diferente para las crías. Sin embargo, las longitudes fueron significativamente diferentes al nacimiento y en otras etapas del crecimiento, por lo tanto, la curva de crecimiento de la relación peso-longitud mostró una gran variabilidad para las crías de ambos sexos a cualquier edad, a pesar de que no se encontró una alta correlación, la regresión del peso y la longitud fue significativa $\left(r^{2}\right.$ $=0.7024, P<0.001)$. Esta gran variabilidad en el peso y la longitud se debe a los largos periodos de ausencia de las hembras durante su alimentación en el mar. Esto produce cambios drásticos en el peso de las crías debido a la rápida ingesta de leche durante un promedio de 5.03 días de atención por la hembra y una gran perdida de peso durante la ausencia de la madre que dura un promedio de 11.5 días.

Palabras clave: Lobo fino de Guadalupe, Arctocephalus townsendi, Isla Guadalupe, crecimiento de las crías.

Quantitative data on the growth rates of Arctocephalus townsendi pups are nonexistent, and there are few data available on pup and juvenile sizes from the stranding records (Roletto 1984; Webber and Roletto 1987; Hanni et al. 1997). There are several measurements of adult individuals in the field (Fleischer 1978; Gallo-Reynoso and Figueroa-Carranza 1996), but no one of this information relates to the increase of size and body mass until weaning in the wild.

Studies of maternal strategies in Guadalupe fur seals (Figueroa-Carranza 1994; Gallo-Reynoso et al. 2008), Juan Fernández (Francis et al. 1998) and Sub Antarctic fur seals (Georges et al. 2001) show that pups of these three species are exposed to the longest periods of fasting of any otariid while the mother is feeding at sea. Mean duration of feeding trips of Guadalupe fur seal females was found to be 9.0 - 13.5 days (1992 and 1993 respectively with a maximum of 24 days), very long compared to other otariids previously reported (Gallo-Reynoso et al. 2008). The attendance period lasted 5.1 - 6.5 days (1992 and 1993 respectively). The $43.2 \%$ fat rich milk of Guadalupe fur seal females (Figueroa-Carranza 1994), is higher in energy density than that reported for other temperate species, and similar to that of the Sub Antarctic fur seal (Arctocephalus tropicalis) with a mean of 42.8\%, (Georges et al. 2001) and the Juan Fernández fur seal with 41\% (Francis et al. 1998; Georges et al. 2001). In general maternal strategies in fur seals are well known for the sub polar and tropical species, but not much is known about the maternal strategies of temperate fur seals (Schultz and Bowen 2004). Therefore it is interesting to inquire how the attendance pattern and milk energy content affects the growth and weaning size of Guadalupe fur seal pups living in an area of moderate 
primary productivity in a temperate zone. The aim of this study is to describe male and female growth from birth to 220 days, weaning age, of pups born during three consecutive years (1991, 1992 and 1993).

\section{Methods}

Study area.- Isla Guadalupe $\left(29^{\circ} 00^{\prime} \mathrm{N}, 118^{\circ} 15^{\prime} 30^{\prime \prime} \mathrm{W}\right)$ is located $240 \mathrm{~km}$ west of Baja California, México. The island lies within the California Current, the average sea surface temperature is $18^{\circ} \mathrm{C}$ (range: $16^{\circ} \mathrm{C}$ spring, $20^{\circ} \mathrm{C}$ summer; Lynn and Simpson 1987). The orientation of the island $(\mathrm{N}-\mathrm{S}$ ) and its elongated shape $(35 \mathrm{~km}$ long and 6.5-9.5 km wide) act as a barrier against the flow of the current that produces a series of swirls at different depths (Berdegué 1957). Depths of 3,600 m or more surround the island. The coastline and nearshore physiography are composed of loose basaltic rocks and boulders bounded by towering cliffs, with numerous crevices and caves (Pierson 1987).

Pup weighings.- Pups were captured and weighed at three different locations: Arroyitos, Corralitos and Campo Lima, on the eastern side of Isla Guadalupe. Captures were carried out on days when tide was low or when the majority of females of a given male territory were on their feeding trips or floating in rafting groups. Pups were captured using a hoop-net of fine mesh nylon with a bag $1 \mathrm{~m}$ deep and $80 \mathrm{~cm}$ in diameter (Fuhrman Diversified, Seabok, Texas) and once captured they were taken away from the territory to reduce disturbance. Pups were sexed, measured including standard length (tip of nose to tip of tail), fore flipper length, hind flipper length, neck girth, and axilar girth (ASM 1967), their general condition noted (i.e. emaciated, presence of scars, etc) and weighed to the nearest $0.1 \mathrm{~kg}$ with a spring scale (25 kg Jogua, Monterrey, México). Pups were then marked with alphanumeric characters for later identification, using bleach (Wellite, Wella) rubbed in their fur and then released in the capture area. The majority of the marked pups, were recaptured, weighed and measured several times during the breeding seasons of $1991(n=11)$; winter $(n=13)$, summer $(n=40)$ and fall $(n=14)$ of 1992, and in summer of $1993(n=54)$ conforming a sample of 132 pups. As pups grow, they move to pools or to the surf making it more difficult to re-capture them. Of these 132 pups, 11 were newborns with umbilical cord still attached. Thirty four marked pups were measured 149 times, the mean number of morphometrics taken to each pup was 4.4 times (SD = 0.9, range: $3-6$ times). In 1992 the sea took away many marked or known pups (those of females instrumented with a time depth recorder (Gallo-Reynoso et al. 2008)) due to a combination of high surf and high tide, product of Hurricane "Darby" and the El Niño of 1992. As a result of this disturbance additional unmarked orphan pups that drifted to the study area were caught and their measurements and weights taken $(n=8)$ these are included in the total number of pups measured.

As temporal shifts in pupping date affect the estimation of pup ages, the median pupping date for each reproductive season was determined using maximum daily counts of live pups and the sum of dead pups to that date. The mean age (days) of the weighed pups was estimated by adjusting the weighing date by the appropriate median pupping date. Size and body mass means were compared with Student's $t$-test or with a MannWhitney Rank Sum Test with a significance level of 0.05. 
Although growth curves are normally complex, female and male pup body mass show an effectively exponential increase with age (Fig. 1). A weighted linear regression of mean body mass on age was therefore used to estimate growth rate and birth body mass. These were compared in relation to sex and age in days. Weaning body mass was estimated using the regression parameters and a lactation period of 220 days.

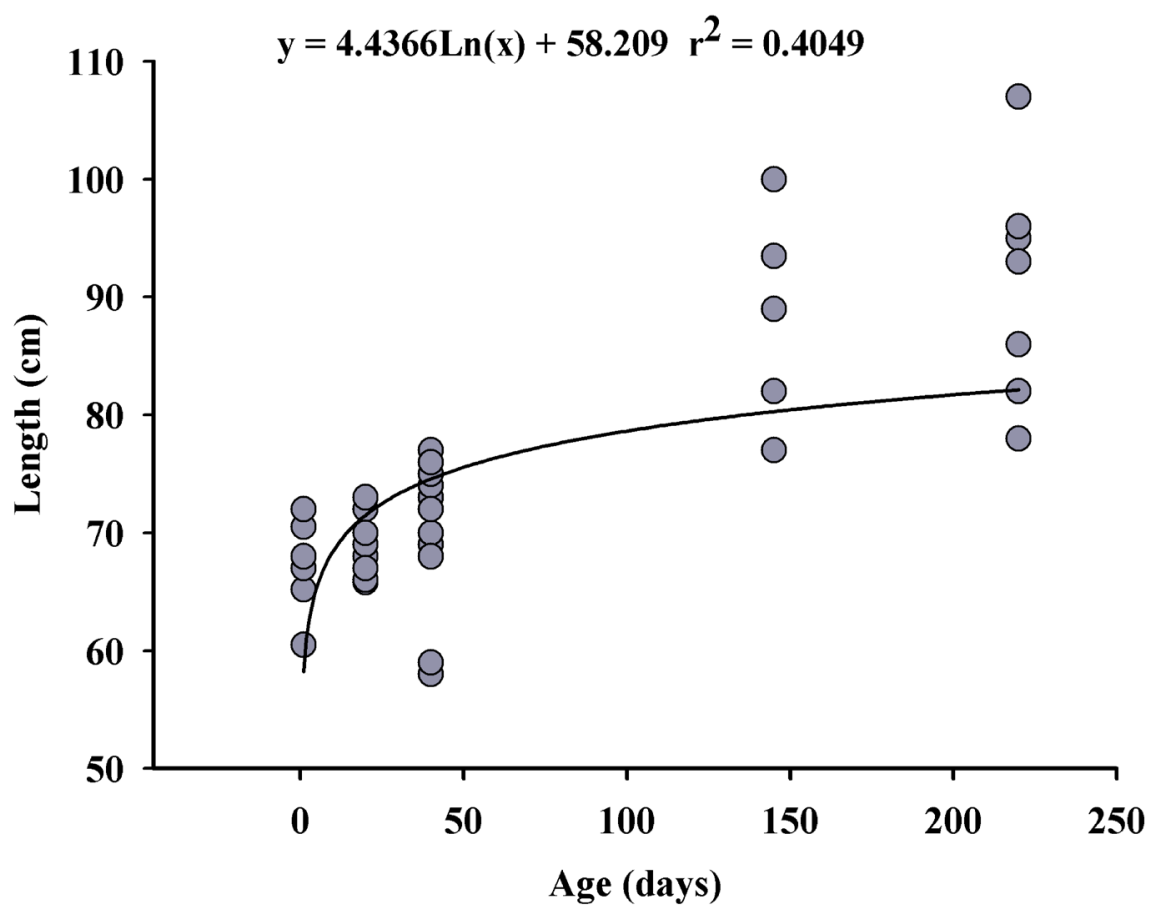

Figure 1. Increase of length of $A$. townsendi male pups from birth to weaning. ( $\mathrm{n}=73$ pups measured). The high variability in the data plotted is due to the long feeding trips of their mothers.

\section{Results}

Body mass.- Mean birth body mass was $4.9 \pm 0.5 \mathrm{~kg}$ (range: $4.0-5.5 \mathrm{~kg}, n=17$ ) for both sexes, around the median birth date of 8 July for three consecutive years; from pups still retaining soft umbilical cord. Mean male birth body mass was $4.9 \pm 0.5 \mathrm{~kg}$ (range: 4-5.5 $\mathrm{kg}, n=7$ ). Mean female birth body mass was $4.9 \pm 0.5 \mathrm{~kg}$ (range: $4.5-5.5 \mathrm{~kg}, n=10$ ). There is no statistical difference between birth body mass of both sexes $(\mathrm{t}=-0.144$, d.f. $=15, P=0.887$ ).

There was no significant difference between the birth body mass of pup cohorts for the different years. Pups born in summer of 1991 had a mean of $4.5 \pm 0.4 \mathrm{~kg}$, $(n=$ 4), with a similar body mass as pups born in summer of 1992, with a mean body mass of $4.9 \pm 0.5 \mathrm{~kg}(n=9)$. Again, there is no statistically significant difference between the 1991 and 1992 weighed pups $(t=-1.266$, d.f. $=11, P=0.232)$. These cohorts appeared lighter than those born in summer of 1993, which had a mean of $5.3 \pm 0.3 \mathrm{~kg}(n=4)$, but there is not a statistically significant difference between pups born either in 1991 and 1993 (Mann-Whitney Rank Sum Test: $\mathrm{T}=11.000 n$ (small) $=4, n($ big $)=4, P=0.057$ ), or between pups born in 1992 and 1993 (Mann-Whitney Rank Sum Test: T = 37.000, $n($ small $)=4, \mathrm{n}($ big $)=9, P=0.188$, Table 1$)$. 
Length.- Mean standard length for newborn pups of both sexes was $64.4 \pm 4.3 \mathrm{~cm}$ (range: 60.5-70.5 cm, $n=17$ ). Mean male birth length was $67.2 \pm 3.7 \mathrm{~cm}$ (range: $60.5-72.0 \mathrm{~cm}$, $n=7$ ), and mean female birth length was $62.5 \pm 3.9 \mathrm{~cm}$ (range: $53-67 \mathrm{~cm}, n=10$ ), there was a significant difference between the lengths of males and females (Mann-Whitney Rank Sum Test: $T=85.000, n($ small $)=7, n(b i g)=10,(P=0.036)$, males being longer than females at birth (Table 1).

Pups born during the summer of 1991 were somewhat smaller $(x=62.6 \pm 2.4 \mathrm{~cm}$, $n=4)$ than pups born during the summer of $1992(\mathrm{x}=65.6 \pm 2.7 \mathrm{~cm}, n=9)$; however, there was no significant difference between both cohorts $(t=-1.938$, d.f. $=11, P=$ 0.079). Also there was no significant difference between pups born in summer 1991 with pups born on summer $1993(\mathrm{t}=-0.202$, d.f. $=6, P=0.847$ ), or of pups born in 1992 with pups born in 1993 ( $\mathrm{x}=63.5 \pm 7.2 \mathrm{~cm}, n=4$ ) (Mann-Whitney Rank Sum Test: T= 27.000, $n($ small $)=4, n($ big $)=9, P=0.938)$.

\begin{tabular}{|c|c|c|c|c|c|c|c|c|c|}
\hline \multirow{2}{*}{$\begin{array}{l}\text { Table 1. Morphometrics } \\
\text { of newborn A. townsen- } \\
\text { di pups at Isla Guada- } \\
\text { lupe in three consecu- } \\
\text { tive years. }\end{array}$} & \multicolumn{5}{|c|}{ Males } & \multicolumn{4}{|c|}{ Females } \\
\hline & & & $\begin{array}{c}\text { Mass } \\
(\mathrm{kg})\end{array}$ & $\begin{array}{l}\text { Length } \\
(\mathrm{cm})\end{array}$ & $\begin{array}{l}\text { Axilar girth } \\
(\mathrm{cm})\end{array}$ & & $\begin{array}{l}\text { Mass } \\
(\mathrm{kg})\end{array}$ & $\begin{array}{l}\text { Length } \\
(\mathrm{cm})\end{array}$ & $\begin{array}{l}\text { Axilar girth } \\
\quad(\mathrm{cm})\end{array}$ \\
\hline & Date & $\mathrm{n}$ & $\begin{array}{l}\text { Mean } \pm \text { SD } \\
\quad \text { (range) }\end{array}$ & $\begin{array}{l}\text { Mean } \pm S D \\
\quad \text { (range) }\end{array}$ & $\begin{array}{l}\text { Mean } \pm \text { SD } \\
\quad \text { (range) }\end{array}$ & $\mathrm{N}$ & $\begin{array}{l}\text { Mean } \pm \text { SD } \\
\quad(\text { range })\end{array}$ & $\begin{array}{l}\text { Mean } \pm S D \\
\quad \text { (range) }\end{array}$ & $\begin{array}{l}\text { Mean } \pm \text { SD } \\
\quad(\text { range })\end{array}$ \\
\hline & $\begin{array}{c}\text { Summer } \\
1991\end{array}$ & 1 & (4.0) & $\left(\begin{array}{c}- \\
(60.5)\end{array}\right.$ & $(40.0)$ & 3 & $\begin{array}{l}4.7 \pm 0.2 \\
(4.5-5.5)\end{array}$ & $\begin{array}{c}63.3 \pm 1.9 \\
(62.0-66.0)\end{array}$ & $\begin{array}{c}44 \pm 2.8 \\
(42.0-48.0)\end{array}$ \\
\hline & $\begin{array}{c}\text { Summer } \\
1992\end{array}$ & 4 & $\begin{array}{l}5.2 \pm 0.3 \\
(4.7-5.5)\end{array}$ & $\begin{array}{c}67.4 \pm 1.9 \\
(65.2-70.5)\end{array}$ & $\begin{array}{c}39.6 \pm 4.6 \\
(35.6-47.0)\end{array}$ & 5 & $\begin{array}{l}4.7 \pm 0.5 \\
(4.0-5.5)\end{array}$ & $\begin{array}{c}64.2 \pm 1.9 \\
(62.0-67.0)\end{array}$ & $\begin{array}{c}42.5 \pm 3.2 \\
(39.0-48.0)\end{array}$ \\
\hline & $\begin{array}{c}\text { Summer } \\
1993\end{array}$ & 2 & $\begin{array}{c}5.0 \pm 0.0 \\
(5.0)\end{array}$ & $\begin{array}{c}70.0 \pm 2.0 \\
(68.0-72.0)\end{array}$ & $\begin{array}{c}44.5 \pm 1.5 \\
(43.0-46.0)\end{array}$ & 2 & $\begin{array}{c}5.5 \pm 0.0 \\
(5.5)\end{array}$ & $\begin{array}{c}57 \pm 4 \\
(53.0-61.0)\end{array}$ & $\begin{array}{c}47.5 \pm 0.5 \\
(47.0-48.0)\end{array}$ \\
\hline & Mean & 7 & $\begin{array}{c}4.9 \pm 0.4 \\
(4-5.5)\end{array}$ & $\begin{array}{c}67.2 \pm 3.5 \\
(60.5-72.0)\end{array}$ & $\begin{array}{l}41.06 \pm 4.2 \\
(35.6-47.0)\end{array}$ & 10 & $\begin{array}{c}4.9 \pm 0.5 \\
(4-5.5)\end{array}$ & $\begin{array}{c}62.5 \pm 3.7 \\
(53.0-67.0)\end{array}$ & $\begin{array}{c}44 \pm 3.4 \\
(39.0-48.0)\end{array}$ \\
\hline
\end{tabular}

Axilar girth.- Mean axilar girth for newborn pups of both sexes was $42.8 \pm 4.1 \mathrm{~cm}$ (range: 35.6-48.0 cm, $n=17$ ). Mean male axilar girth was $41.1 \pm 4.5 \mathrm{~cm}$ (range: $35.6-47.0 \mathrm{~cm}$, $n=7$ ). Mean female axilar girth was $44.0 \pm 3.5 \mathrm{~cm}$ (range: $39.0-48.0 \mathrm{~cm}, n=10$ ). Axilar girth was non-significantly different between the sexes $(t=1.482$, d.f. $=15, P=0.159)$ (Table 1).

Pups born in summer 1991 had larger axilar girths $(x=43.0 \pm 3.0 \mathrm{~cm}, n=4)$, than pups born in summer $1992(\mathrm{x}=41.2 \pm 4.2 \mathrm{~cm}, n=9)$, there was no significant difference between both cohorts $(t=0.712$, d.f. $=11, P=0.491)$. The cohort of summer 1993 had the largest axilar girth $(x=46 \pm 1.9 \mathrm{~cm}, n=4)$ compared to pups of 1991, but there was no significant difference $(\mathrm{t}=-1.470, d . f .=6, P=0.192)$; also between the cohorts of 1992 and 1993, there was no significant difference $(t=-2.027, d . f .=11, P=0.068)$. 


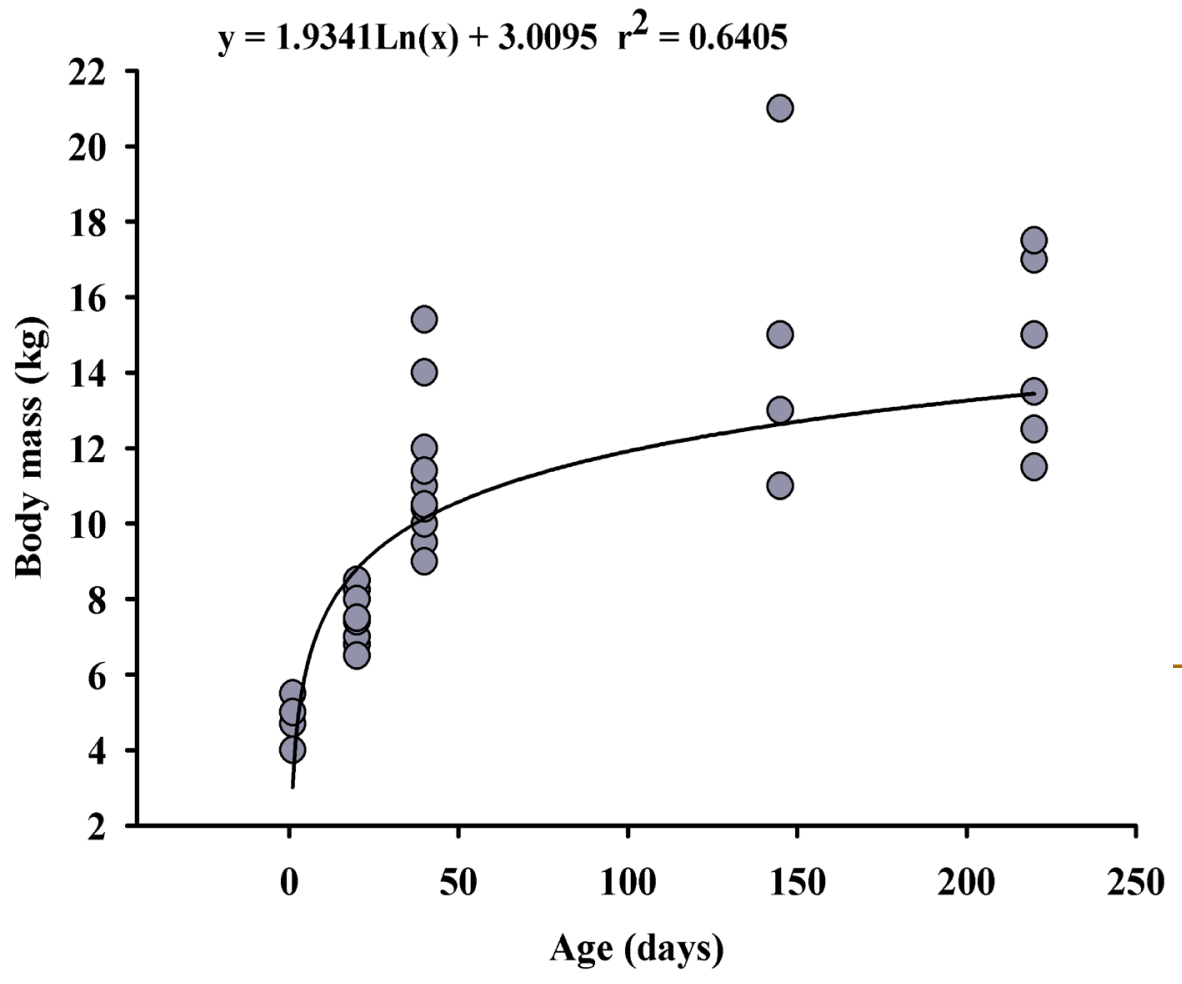

Figure 2. Increase of body mass of $A$. townsendi male pups from birth to weaning. ( $n=73$ pups measured). The high variability in the data plotted is due to the long feeding trips of their mothers.

Growth.- Males were slightly heavier and larger than females at birth, 20, 40 and 220 days, but were somewhat smaller than females at age 145 days, suggesting an equilibration of mass and size between the sexes prior to weaning at around $14 \mathrm{~kg}$ with a length of $89 \mathrm{~cm}$ (combining males $(n=26)$ and females $(n=21))$ (Figures 1, 2, 3, and 4 ; Tables 2, 3, and 4).

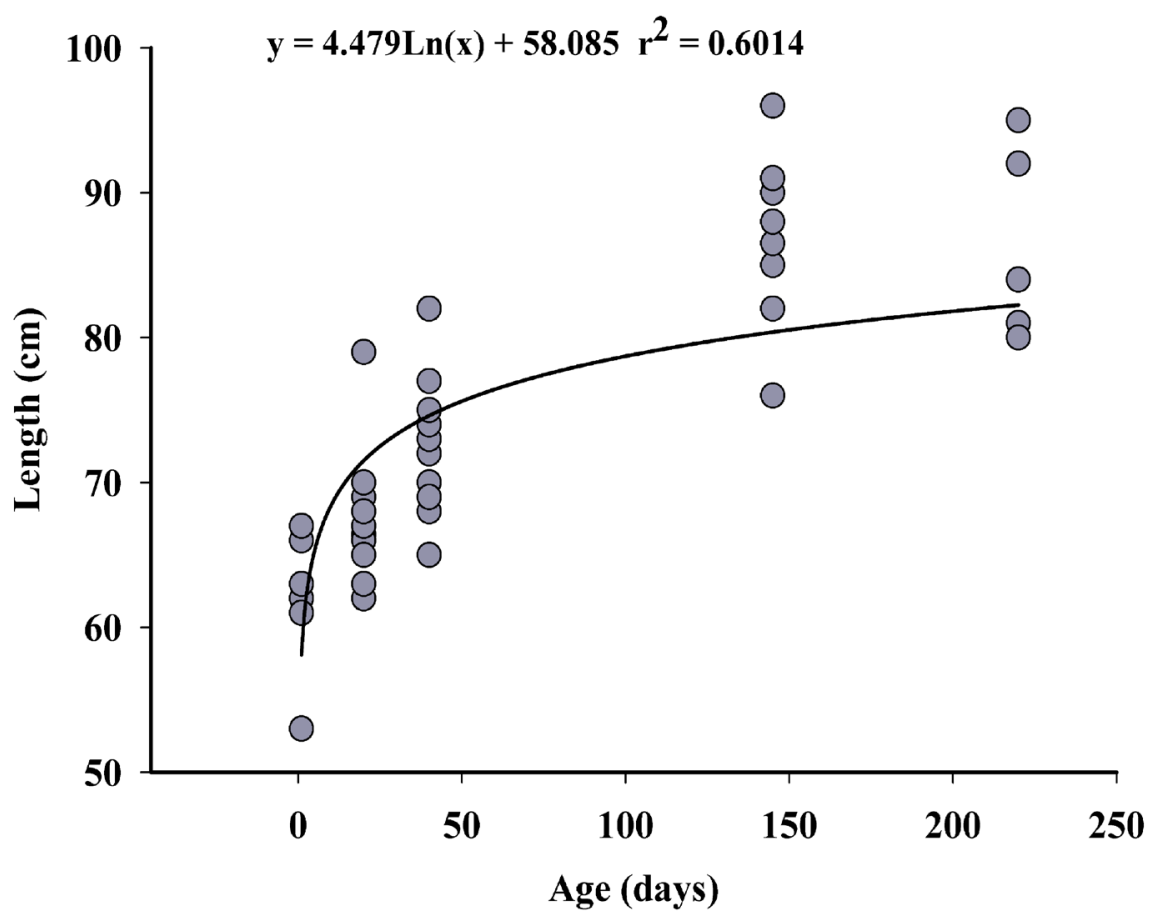

Figure 3. Increase of length of $A$. townsendi female pups from birth to weaning. ( $\mathrm{n}=58$ pups measured). The high variability in the data plotted is due to the long feeding trips of their mothers. 
Growth was exponential until the age of 145 days, from here to 220 days it stabilized at weaning, which takes place between February and March at $9-10$ months of age (220 - 250 days after the median birth date). Males grew faster than females in 1991 and at an equal rate in 1992 and 1993. From birth to 20 days of age males appeared heavier $(x=7.3 \pm 0.7 \mathrm{~kg}, n=26)$ than females $(x=6.9 \pm 0.9 \mathrm{~kg}, n=21)$, but there was no significant difference between the sexes (Mann-Whitney Rank Sum Test: $T$ $=428.500, n($ small $)=21, n(\mathrm{big})=26, P=0.108)$. Males were also slightly larger $(\mathrm{x}=$ $68.4 \pm 1.9 \mathrm{~cm}, n=26)$ than females $(x=67.5 \pm 3.5 \mathrm{~cm}, n=21)$, although, there is no statistical significant difference (Mann-Whitney Rank Sum Test: $\mathrm{T}=434.000, n($ small) $=$

Figure 4. Body mass increase of $A$. townsendi female pups from birth to weaning. $(\mathrm{n}=58$ pups measured). The high variability in the data plotted is due to the long feeding trips of their mothers. Note to the lower right the individual with a high loss of body mass, probably due to have been weaned by the mother.

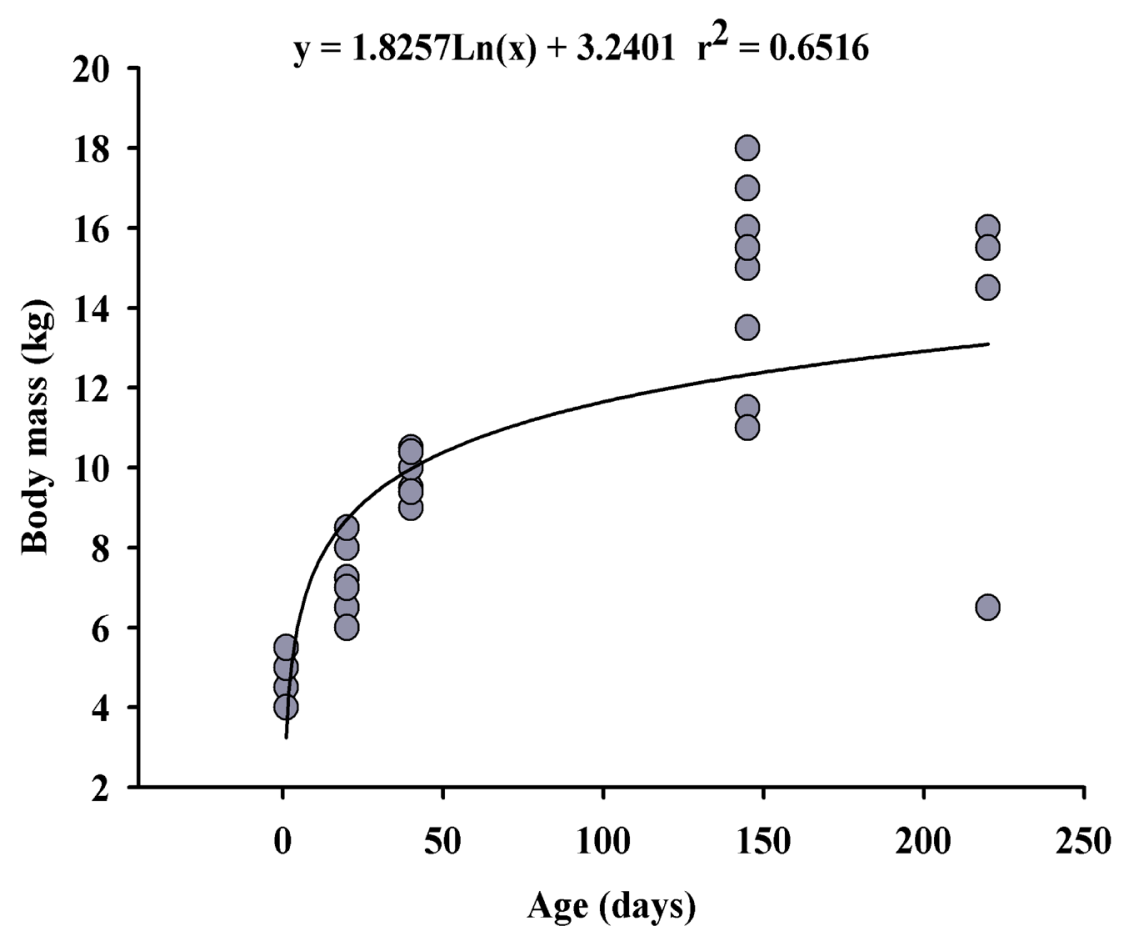

$21, n($ big $)=26, P=0.137)$.

At 40 days of age, males were heavier $(x=10.6 \pm 1.4, \mathrm{~kg}, n=28)$ than females $(x=9.7$ $\pm 0.6 \mathrm{~kg}, n=13$ ), a statistically significant difference (Mann-Whitney Rank Sum Test: T $=189.500, n(\mathrm{small})=13, n(\mathrm{big})=28, P=0.020)$. Males are slightly shorter $(\mathrm{x}=71.2 \pm$ $4.7 \mathrm{~cm}, n=28)$ than females $(x=72.1 \pm 4.6 \mathrm{~cm}, n=13)$, but there is not a significant difference $(\mathrm{t}=-0.585$, d.f. $=39, P=0.562)$

At 145 days males are similar in mass $(x=14.2 \pm 3.7 \mathrm{~kg}, n=5)$ than females $(x=$ $14.8 \pm 2.4 \mathrm{~kg}, n=9)$, and again there is no significant difference $(\mathrm{t}=-0.337$, d.f. $=12$, $\mathrm{P}=0.742)$. The same occurs with male $(\mathrm{x}=88.3 \pm 9.1 \mathrm{~cm}, n=5)$ and female length $(\mathrm{x}$ $=86.3 \pm 5.9 \mathrm{~cm}, n=9)$ in which there is no significant difference $(\mathrm{t}=0.509$, d.f. $=12$, $\mathrm{P}=0.620)$.

While the body mass of males at 220 days, weaning age, was slightly heavier $(x=14.3 \pm 2.0 \mathrm{~kg}, n=8)$ than females $(x=13.7 \pm 4.1 \mathrm{~kg}, n=5)$ this difference was not significant $(\mathrm{t}=0.324$, d.f. $=11, \mathrm{P}=0.752)$. Similarly, even though males were noticeably longer $(x=91.3 \pm 9.0 \mathrm{~cm}, n=8)$ than females $(x=86.4 \pm 6.7 \mathrm{~cm}, n=5)$, this difference was not significant $(\mathrm{t}=1.023, d . f .=11, \mathrm{P}=0.328)$. It is important to note that 
no significant increase in either growth measure occurred between 145 and 220 days.

Pups born during 1992 were raised more successfully to 20 - 40 days than pups born in 1991, and at a similar rate than pups born in 1993. The differences in pup mass between these years were probably due to an increase in sea surface water temperature during the El Niño, at the beginning of this event, it was apparently producing the inverse situation experienced by other fur seals populations affected by El Niño, events like in Galapagos fur seals (Trillmich and Limberger 1985), pups were raised better until 40 days of age, then at the beginning of August pup mortality increased as the length of the female feeding trip increased, perhaps due that mothers were unable to find enough food (Gallo-Reynoso 1994). That year (1992) great pup mortality was caused by Hurricane Darby that struck the colony during the pupping peak date on 3 July, this event killed $33 \%$ of the newborn pups produced in the colony, almost four times the mean pup mortality for the whole colony in non El Niño year (1991 and 1993) calculated at 9\% (Gallo-Reynoso 1994).

\begin{tabular}{|c|c|c|c|c|c|}
\hline Year & Sex & $\begin{array}{l}\text { Period } \\
\text { (days) }\end{array}$ & $\begin{array}{l}\text { Absolute } \\
\text { Increase } \\
\text { (g) }\end{array}$ & $\begin{array}{l}\text { Relative } \\
\text { increase } \\
(\%)\end{array}$ & $\begin{array}{c}\text { Daily } \\
\text { Increase } \\
\text { (g) }\end{array}$ \\
\hline \multirow[t]{8}{*}{1991} & M & Birth-20 & 3000 & 75 & 150.0 \\
\hline & $\mathrm{F}$ & & 2000 & 44.4 & 100 \\
\hline & M & $20-40$ & 3000 & 42.9 & 150 \\
\hline & $\mathrm{F}$ & & 3500 & 53.9 & 175 \\
\hline & M & $40-145$ & 3590 & 50 & 34.2 \\
\hline & $F$ & & 5000 & 50 & 47.6 \\
\hline & M & $145-220$ & 2500 & 16.7 & 33.3 \\
\hline & $\mathrm{F}$ & & 1000 & 6.7 & 13.3 \\
\hline \multirow[t]{4}{*}{1992} & M & Birth-20 & 3500 & 70 & 175 \\
\hline & $\mathrm{F}$ & & 3000 & 61.9 & 150 \\
\hline & $M$ & $20-40$ & 3710 & 50.9 & 185.5 \\
\hline & $\mathrm{F}$ & & 3060 & 44.1 & 153 \\
\hline \multirow[t]{4}{*}{1993} & M & Birth-20 & 3500 & 70 & 175 \\
\hline & $\mathrm{F}$ & & 3000 & 61.9 & 150 \\
\hline & M & $20-40$ & 3320 & 45.5 & 166 \\
\hline & $\mathrm{F}$ & & 3460 & 49.9 & 173 \\
\hline
\end{tabular}

Table 2. Absolute, relative and daily mass gains of male and female Guadalupe fur seal pups.

Body mass-length relationships.- The body mass of both sexes were not significantly different for the Guadalupe fur seal pups, whereas lengths were significantly different at birth and at several other stages, therefore, the linear regression equation was adjusted mixing both sexes (Fig. 5) and the growth curve of body mass-length relationship showed a very high variability in both body mass and length of all the pups of both sexes at any age. The regression was significant $\left(r^{2}=0.7024, P<0.001\right.$, Fig. 5). That high variability is due to the days in which pups were captured and weighed, meaning that some pups were captured and weighed the same day or a day after their mother's had nursed them and departed for another feeding trip; other pups were captured and measured when the mother has not yet returned from a long trip to nurse, and the pup was fasting for some 
days. It was illustrated by a pre-weaning female pup that fasted for a very long time, showing a negative increase in body mass, while maintaining a normal length for her age (see Fig. 4).

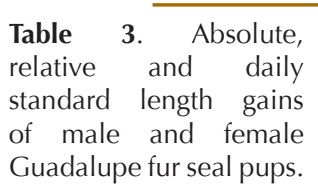

\begin{tabular}{|c|c|c|c|c|c|}
\hline Year & Sex & $\begin{array}{l}\text { Period } \\
\text { (days) }\end{array}$ & $\begin{array}{c}\text { Absolute } \\
\text { increase } \\
(\mathrm{mm})\end{array}$ & $\begin{array}{c}\text { Relative } \\
\text { increase } \\
(\%)\end{array}$ & $\begin{array}{c}\text { Daily } \\
\text { increase } \\
\text { (mm) }\end{array}$ \\
\hline \multirow[t]{8}{*}{1991} & $\mathrm{M}$ & Birth-20 & 67 & 11.1 & 3.4 \\
\hline & $\mathrm{F}$ & & 60 & 9.7 & 3.0 \\
\hline & $\mathrm{M}$ & $20-40$ & 73 & 10.9 & 3.7 \\
\hline & $\mathrm{F}$ & & 49 & 7.3 & 2.5 \\
\hline & $\mathrm{M}$ & $40-145$ & 138 & 18.5 & 1.3 \\
\hline & $\mathrm{F}$ & & 142 & 19.7 & 0.1 \\
\hline & $\mathrm{M}$ & $145-220$ & 30 & 3.4 & 0.4 \\
\hline & $\mathrm{F}$ & & 40 & 4.6 & 0.5 \\
\hline \multirow[t]{4}{*}{1992} & $\mathrm{M}$ & Birth-20 & 60 & 8.6 & 3.0 \\
\hline & $\mathrm{F}$ & & 60 & 9.5 & 3.0 \\
\hline & $\mathrm{M}$ & $20-40$ & 50 & 7.4 & 2.5 \\
\hline & $\mathrm{F}$ & & 50 & 7.1 & 2.5 \\
\hline \multirow[t]{4}{*}{1993} & $\mathrm{M}$ & Birth-20 & 60 & 9.0 & 3.0 \\
\hline & $\mathrm{F}$ & & 60 & 9.8 & 3.0 \\
\hline & $\mathrm{M}$ & $20-40$ & 60 & 8.6 & 3.0 \\
\hline & $\mathrm{F}$ & & 50 & 7.1 & 2.5 \\
\hline
\end{tabular}

\section{Discussion}

Birth body mass of Guadalupe fur seals pups was found to be similar to those of other temperate fur seals. Body mass at birth is a reflection of prenatal maternal investment and has been found to represent a similar proportion of maternal body mass among 10 otariid and 11 phocid species (Costa 1991b; Costa 2008). Body mass at birth for phocids represents $9 \%( \pm 2.7)$, and for otariids $11 \%( \pm 2.8)$ of maternal mass (Bowen 1991; Costa 2008). In the case of the Guadalupe fur seal, pup mass at birth ( $x=4.9 \pm 0.5 \mathrm{~kg}$, range: $4-5.5, n=17)$ represents $10 \%$ of maternal body mass ( $x=49.1 \pm 5.7 \mathrm{~kg}$, range: $40-55$, $n=14$ (Gallo-Reynoso 1994)), in this case a value less than the mean for other otariids, although an increase in sample size might change this values.

Annual differences in birth body mass may be related to differences in the amount of resources available to females or distance to which females have to travel to find food. It has been shown that food restriction during pregnancy reduces birth body mass of the offspring.

A correlation between trip duration and energy delivery per trip for otariid mothers has been described by Costa (1991b); this relationship is consistent with the predictions of central place foraging theory (Orians and Pearson 1977), which predicts the optimal behavior of animals foraging at varying distance from a central place such as a rookery. According to this theory the females of Guadalupe fur seal that forages at long distance from the rookery with round trips averaging 2,375 $\pm 1,389 \mathrm{~km}$, and a mean distance to feeding grounds of about $444 \pm 151 \mathrm{~km}$ from Guadalupe Island (Gallo-Reynoso et 


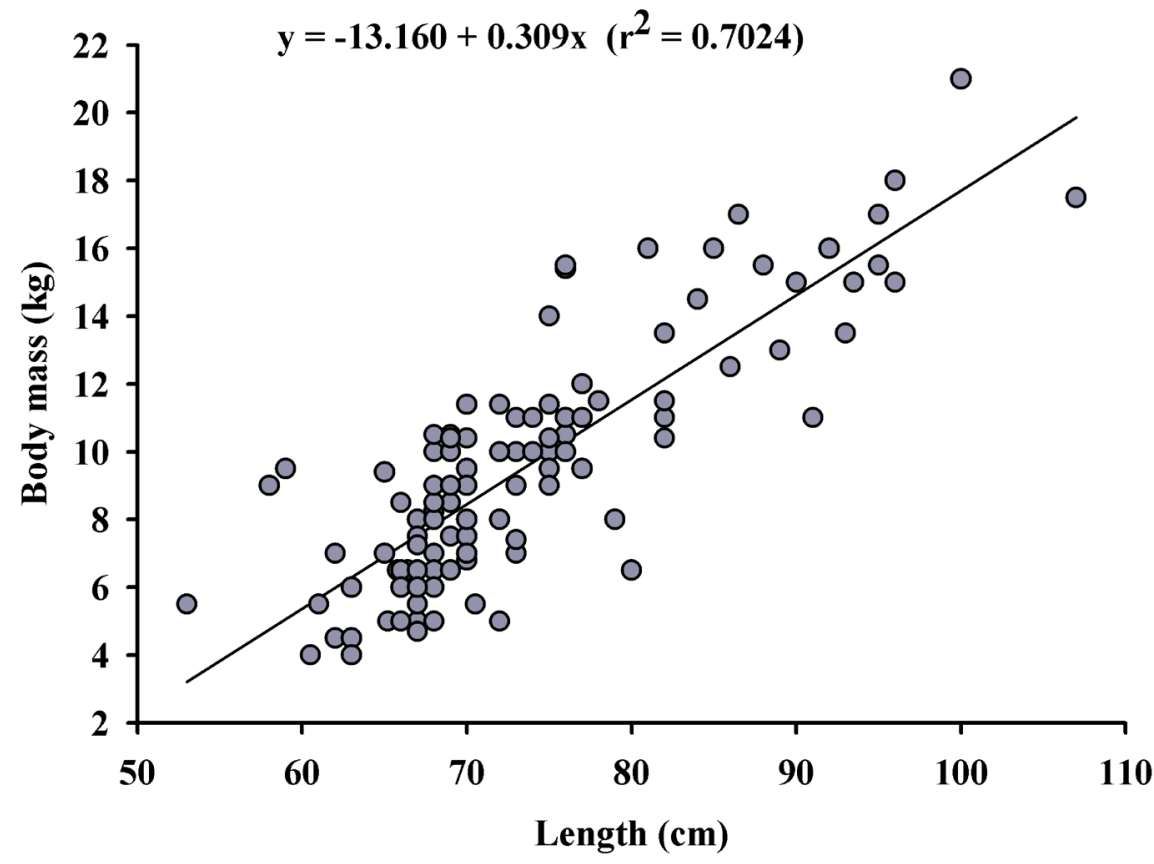

Figure 5. Mass-length relationship of Guadalupe fur seals pups of both sexes showing a significant regression $\left(\mathrm{r}^{2}=\right.$ $0.7024, \mathrm{P}<0.001)$. Note the high variability of the measures at any stage of growth due to the long feeding trip of the mothers, mean trip duration was $9.0 \pm 6.4$ days in 1992 and $13.5 \pm 7.0$ days in 1993. Pup attendance period lasted 5.1 \pm 3.5 days in 1992 and $6.5 \pm 3.9$ days in 1993 .

al. 2008), should have a very high energy milk to compensate for these long foraging distances. The trips of Guadalupe fur seal females are twice as long as trips made by Antarctic fur seal (A. gazella) females that travel approximately $200 \mathrm{~km}$ to feed (Croxall et al. 1985) and northern fur seals (Callorhinus ursinus) which travel 160-200 km (Loughlin et al. 1987; Goebel et al. 1991) and similar to that of the Juan Fernández fur seal (A. philippii) which travel around $500 \mathrm{~km}$ to their feeding grounds (Francis et al. 1998). In contrast,

\begin{tabular}{|c|c|c|c|c|c|}
\hline Year & Sex & $\begin{array}{l}\text { Period } \\
\text { (days) }\end{array}$ & $\begin{array}{c}\text { Absolute } \\
\text { increase } \\
(\mathrm{mm})\end{array}$ & $\begin{array}{c}\text { Relative } \\
\text { increase } \\
(\%)\end{array}$ & $\begin{array}{c}\text { Daily } \\
\text { increase } \\
(\mathrm{mm})\end{array}$ \\
\hline \multirow[t]{8}{*}{1991} & M & Birth-20 & 64 & 16 & 3.2 \\
\hline & $F$ & & 60 & 14.3 & 1.6 \\
\hline & $M$ & $20-40$ & 71 & 15.3 & 3.6 \\
\hline & $\mathrm{F}$ & & 70 & 14.4 & 3.5 \\
\hline & $M$ & $40-145$ & 119 & 22.2 & 11.3 \\
\hline & $\mathrm{F}$ & & 103 & 18.7 & 9.8 \\
\hline & $M$ & $145-220$ & 46 & 7.0 & 0.6 \\
\hline & $F$ & & 36 & 5.5 & 0.5 \\
\hline \multirow[t]{4}{*}{1992} & $M$ & Birth-20 & 61 & 14.0 & 3.1 \\
\hline & $F$ & & 52 & 12.2 & 2.6 \\
\hline & $M$ & $20-40$ & 57 & 11.5 & 2.9 \\
\hline & $F$ & & 82 & 17.2 & 4.1 \\
\hline \multirow[t]{4}{*}{1993} & M & Birth-20 & 73 & 16.4 & 3.7 \\
\hline & $\mathrm{F}$ & & 65 & 13.8 & 3.3 \\
\hline & M & $20-40$ & 52 & 10.0 & 2.6 \\
\hline & $\mathrm{F}$ & & 55 & 10.3 & 2.8 \\
\hline
\end{tabular}

Table 4. Absolute, relative and daily axilar girth length gains of male and female Guadalupe fur seal pups. 
females feeding close to the rookery should make many short trips with a comparatively lower energy return per trip. This is consistent with data of species in which the energy delivery per trip has been studied (Table 6, fur seals: northern, Antarctic, South African, Subantarctic, New Zealand, Galapagos, South American fur seals; sea lions: Steller's and California) (Costa 1991b; Figueroa-Carranza 1994). The $43 \%$ fat content of the milk in this species with a mean of 11.5 day foraging trips (Figueroa-Carranza 1994) is similar than that reported for other temperate species that makes long foraging trips, such as the Sub Antarctic fur seal (A. tropicalis) with $42.8 \%$ and nine day foraging trips (Georges et al. 2001) and the Juan Fernández fur seal $41 \%$ with 10 day foraging trips (Francis et al. 1998) and it is consistent with the high rates of growth of the pups of these species.

In Guadalupe fur seals the wide variation in pup mass over the nursing period reflects the long duration of foraging trips, and the corresponding long duration of attendance to pups. During a female visit to nurse her pup, the pup may gain $5.7 \mathrm{~kg}$ in five days and then be left fasting for another 11.5 days (with a maximum recorded of 33 days, Table 5). Studies of maternal strategies in Guadalupe fur seals (Figueroa-Carranza 1994; Gallo-Reynoso 1994) showed that pups are exposed to the longest periods of fasting of any otariid while the mother is feeding at sea. Mean trip duration was $9.0 \pm 6.4$ days in 1992 and $13.5 \pm 7.0$ days in 1993, with a maximum of 33 days in 1991 (GalloReynoso et al. 2008). Pup attendance period lasted $5.1 \pm 3.5$ days in 1992 and $6.5 \pm 3.9$ days in 1993 (Gallo-Reynoso et al. 2008).

Payne (1979) has shown that the Antarctic fur seal at Bird Island, South Georgia has the fastest pup growth rate and one of the shortest lactation periods of any fur seal. He suggested that this is related to females making relatively short trips to sea to feed on Antarctic krill (Euphausia superba), an abundant resource around their breeding sites. Other fur seals feed mainly on fish and squid (Rand 1959; Street 1964; Perez and Bigg 1986; Gallo-Reynoso et al. 2008; Ochoa and Francis 1995) which are found scattered and often farther away. Guadalupe fur seal pups growth rate is similar to those of other

\begin{tabular}{|c|c|c|c|c|c|c|c|c|c|c|c|}
\hline $\begin{array}{l}\text { Table 5. Comparative } \\
\text { data on lactation, nursing, } \\
\text { content of fat in milk, } \\
\text { milk energetic content, } \\
\text { attendance patterns, and } \\
\text { growth over the first } 60 \\
\text { days of life of Guadalupe }\end{array}$ & $\begin{array}{l}\text { Mean } \\
\text { duration } \\
\text { of } \\
\text { lactation } \\
\text { period } \\
\text { (days) }\end{array}$ & $\begin{array}{c}\% \\
\text { time } \\
\text { on } \\
\text { land }\end{array}$ & $\begin{array}{c}\text { Mean } \\
\text { total } \\
\text { days } \\
\text { spent } \\
\text { w/ } \\
\text { pup }\end{array}$ & $\begin{array}{l}\text { \% visit } \\
\text { time } \\
\text { spent } \\
\text { nursing }\end{array}$ & $\begin{array}{c}\text { Mean } \\
\text { total } \\
\text { hours } \\
\text { nursing }\end{array}$ & $\begin{array}{c}\% \\
\text { fat } \\
\text { in } \\
\text { milk }\end{array}$ & $\begin{array}{c}\text { Milk } \\
\text { energy } \\
\text { content } \\
(\mathrm{MJ} / \mathrm{g})\end{array}$ & $\begin{array}{c}\text { Weaning } \\
\text { age } \\
\text { (months) }\end{array}$ & $\begin{array}{c}\text { Mean } \\
\text { visit } \\
\text { duration } \\
\text { (days) }\end{array}$ & $\begin{array}{l}\text { Mean } \\
\text { trip } \\
\text { duration } \\
\text { (days) }\end{array}$ & $\begin{array}{l}\text { Pup } \\
\text { growth } \\
\text { (g/day) } \\
\text { Mal. } \\
\text { Fem. }\end{array}$ \\
\hline $\begin{array}{l}\text { fur seals (taken from } \\
\text { Figueroa-Carranza 1994). }\end{array}$ & 270 & 36 & 97.2 & 18.5 & 431.8 & 43 & 20.60 & $9-10$ & 5.03 & 11.5 & $\begin{array}{c}88 \\
110\end{array}$ \\
\hline
\end{tabular}

temperate species such as Juan Fernández fur seals (Ochoa 1995).

Costa et al. (1988) demonstrated that larger Antarctic fur seal females give birth to larger pups, and that neonatal size is scaled to the 0.6 power of maternal body mass. We found a similar difference even though the sample size is small, the tendency is very clear; experienced females giving birth in the same territory in three consecutive years) $\left(r^{2}=\right.$ $0.922(y=4.405+0.583(x)), P<0.001, n=7$ pairs of mothers with pups of both sexes) gave birth to heavier pups, also larger females, in the range of 50 to $55 \mathrm{~kg}$ gave birth to larger pups than females in the range of 40 to $48 \mathrm{~kg}\left(r^{2}=0.935(y=0.421+0.111(x))\right.$, 
$P<0.001, n=7$ pairs of mothers with pups of both sexes).

Guadalupe fur seal pups double their mass within the first 70 days of life, Juan Fernández at 73 days and Galápagos and South African fur seals double their birth mass at 72 days (Trillmich and Lechner 1986; Gentry et al. 1986). The similarity among these species is remarkable, given the wide difference in the attendance pattern of energy transfer from the mother to the pup. Guadalupe fur seals must be able to suckle and digest high fat-content milk (Figueroa-Carranza 1994) at a faster rate than other otariid pups, in order to compensate for the smaller proportion of time mothers are available to suckle (Figueroa-Carranza 1994, Gallo-Reynoso 1994).

\begin{tabular}{|c|c|c|c|c|c|c|c|}
\hline Species & $\begin{array}{c}\text { Nursing } \\
\text { days }\end{array}$ & $\begin{array}{l}\% \text { Time } \\
\text { on land }\end{array}$ & $\begin{array}{c}\text { Total } \\
\text { days } \\
\text { with pup }\end{array}$ & $\begin{array}{l}\% \text { Time } \\
\text { on land } \\
\text { nursing }\end{array}$ & $\begin{array}{c}\text { Total } \\
\text { hours } \\
\text { nursing }\end{array}$ & $\begin{array}{c}\text { Energetic } \\
\text { content } \\
(\mathrm{MJ} / \mathrm{g})\end{array}$ & $\begin{array}{c}\text { Pup growth (g } \\
\text { /day) } \\
\text { Males - } \\
\text { Females }\end{array}$ \\
\hline C. ursinus & 120 & 27 & 32.4 & $30-45$ & 119 & 20.92 & $72-57$ \\
\hline A. gazella & 120 & 35 & 42 & 24 & 242 & 19.65 & $90-76$ \\
\hline A. pusillus & 240 & 45.6 & 109.4 & n.d. & n.d. & 9.79 & $95-65$ \\
\hline A. forsteri & 300 & n.d. & n.d. & 34.3 & n.d. & n.d. & $45-46$ \\
\hline A. tropicalis* & 270 & n.d. & n.d. & n.d. & n.d. & $20.4^{*}$ & $43-37$ \\
\hline A. australis $(U)$ & 240 & n.d. & n.d. & n.d. & n.d. & 14.56 & $58-43$ \\
\hline A. australis $(P)$ & 360 & 23.5 & 84.6 & 60 & 1209 & n.d. & n.d. - n.d. \\
\hline A. galapagoensis & 540 & 40 & 216 & 40 & 2073 & 12.818 & $58-43$ \\
\hline A. townsendi & 270 & 36 & 97.2 & 18.5 & 431.8 & 20.60 & $88-110$ \\
\hline
\end{tabular}

Acknowledgments

We thank Dirección General de Intercambio Académico, UNAM and The National Geographic Society that funded the 1991 expedition, the Institute of Marine Sciences, and B.J. Le Boeuf, University of California, Santa Cruz, funded in part the 1992 expedition. We also thank A. Delgado, M. Peralta and A. Sánchez for their help in the field. We are indebted to Secretaría de Marina and to fishermen of "Cooperativa de langosteros y abuloneros" that provided logistic support on the island. This work was conducted under permits No. 0561 of Secretaría de Pesca, and Nos. 2538, 4933 and 2025 of Secretaría de Desarrollo Urbano y Ecología (now SEMARNAT), México. The manuscript benefit from the comments of D. P. Costa and other two anonymous reviewers.

ASM (American Society of Mammalogists). 1967. Standard measurements of seals. Journal of Mammalogy 48:459-462.

Berdegué, J. 1957. La Isla de Guadalupe, México. Contribución al conocimiento de sus 
recursos naturales renovables. Secretaría de Marina, Dirección General de Pesca e Industrias Conexas, México.

Bowen, W. D. 1991. Behavioral ecology of pinniped neonates. Pp 66-117 in The Behavior of pinnipeds. (Renouf, D. ed.). Chapman and Hall. London.

Costa, D. P. 1991a. Reproductive and foraging energetics in pinnipeds: Implications for life history patterns. Pp 300-338 in The behavior of pinnipeds. (Renouf, D. ed.). Chapman and Hall. London.

Costa, D. P. 1991b. Reproductive and foraging energetics of high latitude penguins, albatrosses and pinnipeds: Implications for life history patterns. American Zoologist 31:111-130.

Costa, D. P., AND R. L. Gentry. 1986. Free-ranging energetics of Northern fur seal. Pp. 79101. in Fur seals: Maternal strategies on land and at sea. (Gentry, R. L., and G.L. Kooyman, eds.). Princeton University Press, Princeton, New Jersey.

Costa, D. P., F. Trillmich, and J. P. Croxall. 1988. Intraspecific allometry of neonatal size in the antarctic fur seal (Arctocephalus gazella). Behavioral Ecology and Sociobiology 22:361-364.

Costa, D. P. 2008 A conceptual model of the variation in parental attendance in response to environmental fluctuation: foraging energetics of lactating sea lions and fur seals. Aquatic Conservation: Marine and Freshwater Ecosystems 17(S1):S44-S52.

Croxall, J. P., I. Everson, G. L. Kooyman, C. Ricketts, and R. W. Davies. 1985. Fur seal diving behaviour in relation to vertical distribution of krill. Journal of Animal Ecology 54:1-8.

Figueroa-Carranza, A. L. 1994. Early lactation and attendance behavior of the Guadalupe fur seal females, (Arctocephalus townsendi). Master in Science Thesis. University of California, Santa Cruz, California.

FleisCHer, L. A. 1978. The distribution, abundance, and population characteristics of the Guadalupe fur seal, Arctocephalus townsendi (Merriam 1897). Master in Science Thesis. University of Washington, Seattle.

Francis, J., D. Boness, and H. Ochoa-Acuña. 1998. A protracted foraging and attendance cycle in females Juan Fernandez fur seals. Marine Mammal Science 14:552-574.

Gallo-Reynoso, J. P. 1994. Factors affecting the population status of Guadalupe fur seals, Arctocephalus townsendi (Merriam, 1897), at Isla de Guadalupe, Baja California, Mexico. Ph. D. Dissertation. University of California, Santa Cruz, California.

Gallo-Reynoso, J. P., and A. L. Figueroa-Carranza. 1996. Size and weight of Guadalupe fur seals. Marine Mammal Science 12:318-320.

Gallo-Reynoso, J. P., A. L. Figueroa-Carranza, and B. J. Le Boeuf. 2008. Foraging behavior of lactating Guadalupe fur seal females. Pp. 595-614, in Avances en el Estudio de los Mamíferos de México II. Publicaciones Especiales, Vol. II (Lorenzo, C., E. Espinoza, y J. Ortega, eds.). Asociación Mexicana de Mastozoología, A. C., Centro de Investigaciones Biológicas del Noroeste, El Colegio de la frontera Sur, Instituto Politécnico Nacional, Universidad Autónoma de Morelos, Universidad Autónoma Metropolitana, Universidad Autónoma de Chiapas y Universidad Veracruzana, San Cristóbal de Las Casas, Chiapas.

Gentry, R. L., D. P. Costa, J. P. Croxall, J. H. M. David, R. W. Davis, G. L. Kooyman, P. Majluf, and F. Trillmich. 1986. Synthesis and conclusions. in Fur seals, Maternal 
strategies on land and at sea. (Gentry, R. L., and G. L. Kooyman, eds.). Princeton University Press. Princeton, New Jersey

Georges, J. Y., R. Groscolas, C. Guinet and J. P. Robin. 2001. Milking strategy in subantarctic fur seals, Arctocephalus tropicalis breeding on Amsterdam Island: Evidence from changes in milk composition. Physiological and Biochemical Zoology 74:548-559.

Goebel, M. E., J. L. Bengstone, R. L. Delong, R. L. Gentry and T. R. Loughuin. 1991. Diving patterns and foraging locations of female northern fur seals. Fishery Bulletin, U.S., 89:171-179.

Hanni, K. D., D. J. Long, R. E. Jones, P. Pyle and L. E. Morgan. 1997. Sightings and strandings of Guadalupe fur seals in Central and Northern California, 1988-1995. Journal of Mammalogy 78:684-690.

Loughin, T. R., J. L. Bengston and R. L. Merrick. 1987. Characteristics of feeding trips of female northern fur seals. Canadian Journal of Zoology 65:2079-2084.

LynN, R. J. AND J. J. Simpson. 1987. The California Current system: the seasonal variability of its physical characteristics. Journal of Geophysical Research 92(c12):12,947$12,966$.

Оснол, Н. 1995. Ecological and physiological factors that influence pup birth weight and postnatal growth of Juan Fernandez fur seals, Arctocephalus philippii. Master in Science Thesis. University of Florida.

Ochoa, H. And J. M. Francis. 1995. Spring and summer prey of the Juan Fernández fur seal, Arctocephalus philippii. Canadian Journal of Zoology 73:1444-1452.

Orians, G. H. and N. E. Pearson. 1977. On the theory of central place foraging. Pp. 153177, in Analysis of Ecological Systems (Horn, D.J. , G.R. Stairs, and R.D. Mitchell, eds.). Ohio State University Press, Columbus, Ohio

Payne, M. R. 1979. Growth in the Antarctic fur seal Arctocephalus gazella. Journal of the Zoological Society of London 187:1-20.

Perez, M. A., AND M. A. Bigg. 1986. Diet of northern fur seal, Callorhinus ursinus off western North America. Fishery Bulletin 84:959-973.

PierSon, M. O. 1987. Breeding behavior of the Guadalupe fur seal, Arctocephalus townsendi. Pp. 83-94, in Status, Biology, and Ecology of fur seals (Croxall, J. P., and R. L. Gentry, eds.). NOAA Technical Report NMFS 51

RAND, R. W. 1959. The Cape fur seal (Arctocephalus pusillus): Distribution, abundance and feeding habits off the southwestern coast of the Cape Province. Invest. Rep. Division of Fisheries of South Africa 34:1-75.

Roletto, J. 1984. The most northerly sighting of a live Guadalupe fur seal, Arctocephalus townsendi, from Princeton, San Mateo County, California. Abstract 62. Second Biennial Conference of Research in California's National Parks. University of California, Davis 5-7 September. 1984.

Schultz, T. M. AND W. D. Bowen. 2004. Pinniped lactation strategies: Evaluation of data on maternal and offspring life history traits. Marine Mammal Science 20:86-114.

StreEt, R. J. 1964. Feeding habits of the New Zealand fur seal (Arctocephalus forsteri). Fisheries Technical Report New Zealand Marine Department 9:1-20.

Trillmich, F. and D. Limberger. 1985. Drastic effects of El Niño on Galapagos pinnipeds. Oecologia 67:19-22.

Trillmich, F. ANd E. Lechner. 1986. Milk of the Galapagos fur seal and sea lion, with 
a comparison of the milk of eared seals (Otariidae). Journal Zoology London 209:271-277.

Webber, M. A. AND J. Roletto. 1987. Two recent occurrences of the Guadalupe fur seal Arctocephalus townsendi in Central California. Bulletin of the Southern California Academy of Sciences

Sometido: 4 octubre 2009

Revisado: 19 enero 2010

Aceptado: 3 febrero 2010

Editor asociado William Z. Lidicker, Jr. 
